НИКОЛАЕВА Ольга Васильевна

доктор филол. наук, доцент, профессор кафедры лингвистики и межкультурной коммуникации Восточного института - Школы региональных и международных исследований ДВФУ (2. Владивосток)

Электронная почта nikolaeva.ov@dvfu.ru

\title{
Коммуникативные практики реализации риторики патриотизма в китайских СМИ на английском языке
}

doi: dx.doi.org/10.24866/2542-1611/2020-1/23-33

\begin{abstract}
Работа посвящена вопросам прагматической эффективности патриотической риторики Китая в англоязычных китайских СМИ. Выявлены китайские традиционные и современные масс-медийные коммуникативные практики. Определена роль фигуральной актуализации концепта внешней угрозы посредством метафоры войны в отношении критических экономических и социальных факторов, и образа великого преодоления для поднятия патриотического духа. Исторические аллюзии и народная мудрость представлены как инструменты традиционной патриотической риторики Китая. Современные масс-медийные коммуникативные практики КНР включают конкретные ресурсы английского языка и англоязычной речевой традиции.
\end{abstract}

Настоящее исследование посвящено анализу традиционнокитайских и современных масс-медийных коммуникативных практик, формирующих прагматическую эффективность патриотической риторики в китайских СМИ на английском языке. Коммуникативные практики в данной работе представлены как речемыслительные нормы и воспроизводимые речеповеденческие тактики, применяемые для трансляции глубоких социальных смыслов, формирующих суть патриотической риторики.

Материалом для исследования послужили китайские массмедиа на английском языке (The Xinhua News Agency, The China Daily, The People`s Daily, The Global Times и другие). Такие источники рассчитаны на широкую целевую аудиторию, включающую как англоговорящих иностранцев, так и соотечественников, живущих и работающих за рубежом. Свободный доступ к электронным версиям фактически сделал англоязычные китайские СМИ открытой трибуной коммуникации Китая со всем остальным миром. В китайских СМИ на английском языке освещаются основные события в стране и за её пределами, значимые для Китая военные и политические проблемы, культурные и экономические вопросы. Англоязычные версии китайских масс-медиа представляют самостоятельные материалы, как правило, не являющиеся переводами с китайского языка. Цель таких изданий в том, чтобы рассказать миру о Китае и осветить позицию Китая на события, происходящие в мире.

Исследование основано на положении о том, что особенностью разных публикуемых материалов (от новостей до аналитических обзоров и комментариев) в китайских СМИ на патриотизм, риторика патриотизма, англоязычные китайские СМИ, прагматика, коммуникативные практики, речеповеденческие тактики, речемыслительные нормы
Для изтирования:

Николаева О. В. Коммуникативные практики реализации риторики патриотизма в китайских СМИ на английском языке // Известия Восточного института. 2020. № 1 . C. 23-33. doi: dx.doi. org/10.24866/2542-1611/2020$1 / 23-33$ 
английском языке является фоновая или рельефная патриотическая риторика. Идентификация и экспликация риторики патриотизма в данных источниках выполнялась на основе определения понятия патриотизма и его особенностей в современном Китае.

Патриотизм как социальная и философская категория включает достаточно широкий спектр как естественных проявлений любви к родине, так и сконструированных «патриотических проектов», от крайних, граничащих с национализмом, форм до духовно-нравственных социальных поведенческих ориентиров. Социолог Дж. Александер отмечает, что патриотизм является одним из смыслов социальной жизни $[1$, с. 42]. Государство, будучи одним из главных архитекторов системы смыслов общественного бытия, посредством политики и идеологии проектирует общую национальную модель патриотизма и её содержательное наполнение [3, с. 1-19]. Естественный патриотизм как любовь к родине дополняется или даже заменяется гражданским патриотизмом, «договорным» или государственным патриотизмом, возникают разного рода «патриотические проекты»: «республиканский патриотизм», «конституционный патриотизм» и др. [9].

Как отмечает А. В. Павлов, патриотизм - это «далеко не просто риторика, но действующая практика. Однако эта практика часто основывается на риторике или же тесно взаимодействует с ней» $[9$, с. 84]. Социолог А. Г. Санина пишет, что на уровне риторики даже такое проявление патриотизма, как единение общества, может реализовываться не через культивирование позитивных ценностей, а на основе негативных факторов тиражирования внешних врагов и милитаризации $[10$, с. 53]. Этот тип патриотизма можно называть лозунговым, демонстративным или ситуативным [2].

В условиях глобализации и широкой международной миграции поиск и реализация адекватной и эффективной риторики патриотизма является весьма сложной проблемой современных сообществ. Новизна настоящего исследования состоит в обращении к коммуникативным практикам, используемым Китаем, в трансляции риторики патриотизма на внешнюю и внутреннюю аудиторию в СМИ на английском языке.

Целью исследования является выявление закономерностей, формирующих прагматическую эффективность патриотической риторики Китая в англоязычных китайских СМИ.

Задачи исследования включают:

- тематизацию дискурса англоязычных китайских СМИ и экспликацию в нём патриотической риторики;

- определение системы языковых средств, использованных для реализации патриотической риторики в англоязычных китайских СМИ;

- установление традиционно-китайских коммуникативных практик для реализации патриотической риторики;

- выявление коммуникативных практик, обусловленных англоязычным дискурсом.

Исследование показало, что риторика патриотизма в китайских СМИ на английском языке, с одной стороны, выделяется рельефно в новостях и репортажах о негативных событиях, в материалах, публикуемых в отношении внешних угроз, а с другой стороны, присутству- 


\begin{tabular}{|c|c|}
\hline $\begin{array}{l}\text { Примеры военной метафоры в } \\
\text { экономическом дискурсе }\end{array}$ & Перевод фрагмента \\
\hline to wage trade wars against the rest of the world & Развязать торговую войну против всего мира \\
\hline such tactics fail most of the time & $\begin{array}{l}\text { Такая тактика почти всегда ведёт к пораже- } \\
\text { нию }\end{array}$ \\
\hline form a united front against such US intimidation & $\begin{array}{l}\text { Создать единый фронт против угроз со сто- } \\
\text { роны США }\end{array}$ \\
\hline two countries should not start trade war & $\begin{array}{l}\text { Две страны не должны начинать торговую } \\
\text { войну }\end{array}$ \\
\hline $\begin{array}{l}\text { China is now being forced to fight back in this } \\
\text { trade war }\end{array}$ & $\begin{array}{l}\text { Китай вынуждают бороться в этой торговой } \\
\text { войне }\end{array}$ \\
\hline find no white flags to mark China's surrender & $\begin{array}{l}\text { Не найдётся белого флага, чтобы показать, } \\
\text { что Китай сдался }\end{array}$ \\
\hline
\end{tabular}

ет неявно, в качестве фона, в освещении текущих неконфликтных событий. Это вполне закономерно, поскольку, по словам А. В. Лубского, «о патриотизме обычно вспоминают в эпоху серьёзных испытаний» [7]. И напротив, патриотическая риторика звучит более отчётливо на фоне внешних вызовов.

Так, в ходе исследования выявлено, что в реализации риторики патриотизма в китайских СМИ на английском языке не последнюю роль играет практика фигуральной актуализации концепта внешней угрозы. Под внешней угрозой могут пониматься не только прямые военные, но и, например, экономические вызовы, а также и социальные обстоятельства, воспринимаемые как угроза поступательному развитию страны.

Например, метафора войны используется и в отношении тарифных санкций США против Китая, или в отношении распространения эпидемии. Отсюда и обилие военной лексики, вызывающей аналогию войны в борьбе с нежелательными экономическими и социальными явлениями.

Харро фон Зенгер, автор книги «Стратагемы: О китайском искусстве жить и выживать», отмечает склонность китайцев с древних времён уподоблять «рыночную площадь» «полю боя», считать мудрость военачальника в сражении схожей с той, что направляет купца в его занятиях торговлей. Автор пишет, что с точки зрения китайцев, многие положения военной теории вполне пригодны для экономического противоборства, например, в предпринимательской борьбе, как и на поле боя, прибегают к стратегии и тактике $[5 ; 6]$.

Следуя этой традиции, в освещении торговой войны с США в прессе КНР используют многочисленные слова и выражения «военной» семантики (Таблица 1).

Освещая в СМИ экономические тарифные санкции США, Китай использует прямые военные (порой жестокие) аллюзии из истории: "The Chinese fought against the US in the bloody Korean War in the early 1950s despite the fact that the US had the absolute military supremacy. So it is wishful thinking that the US can force China to cave in with its bullying
Табл. 1. Репрезентация военной метафоры в экономическом дискурсе. Источник: составлено автором. 


\begin{tabular}{|c|c|}
\hline $\begin{array}{c}\text { Китайская пословица военной тематики в } \\
\text { экономическом дискурсе }\end{array}$ & Перевод пословицы \\
\hline $\begin{array}{l}\text { Brothers fighting at home will unite to fight } \\
\text { against an outsider together }\end{array}$ & $\begin{array}{l}\text { Братья, воюющие между собой дома, объеди- } \\
\text { нятся против общего врага }\end{array}$ \\
\hline The self-conceited troops are destined to lose & Возгордившееся войско обречено на провал \\
\hline
\end{tabular}

Табл. 2. Пословицы военной тематики в экономическом дискурсе. Источник: составлено автором. tariff tactics» [12] / Китайцы боролись против США в кровавой корейской войне в начале 1950-х годов, несмотря на то что у США было абсолютное военное превосходство. Поэтому считать, что США могут заставить Китай сдаться путём применения устрашающей тарифной тактики, означает принять желаемое за действительное.

Эмоциональная компонента патриотической риторики в данном фрагменте ярко обозначена историческим фоном кровавой корейской войны (bloody Korean War), по сравнению с которой экономическая ситуация тарифных санкций США эффектно подаётся как бесперспективная. «Силовая» природа как военных, так и экономических реалий выражена фигуральными и прямыми смыслами: The Chinese fought against; bloody Korean War; military supremacy; force China; bullying tariff tactics.

К традиционным коммуникативным практикам относится обильное цитирование народной мудрости и пословиц. Следует подчеркнуть, что афоризмы и пословицы в речи обнажают глубокие корни китайского коллективизма. Стремление подкрепить свои слова мнением всего народа, мудростью древних мыслителей и опытом многих поколений находится в полном соответствии с пониманием своей принадлежности к большому коллективу и его большому Пути и осознанием себя как его мельчайшей песчинки. В освещении экономических событий часто используются пословицы военной тематики, некоторые примеры которых приведены в Таблице 2.

Метафорический военный сценарий борьбы с эпидемией коронавируса прорисовывается по мере развития ситуации, появляются новые герои, линия фронта, битвы и сражения, поддерживается идея бороться до кони, п, прославляется храбрость и мужество медиков страны (Таблица 3).

Заголовки статей похожи на призывы и лозунги к объединению в борьбе с общим врагом и уверенности в победе: China confident to win decisive victory in fight against epidemic [13] / Китай уверен в решительной победе в борьбе с эпидемией; Solidarity, dedication will help win the war on COVID-19 [18] / Солидарность, самоотверженность помогут выиграть войну с эпидемией.

Военная метафора естественным образом актуализирует ценности единства и сплочённости нации. Ничто не может консолидировать общество так, как совместная борьба против общего врага: demonstrate the power of a nation united with one heart and one soul [18] / продемонстрировать силу нации, объединённой и сердцем, и душой; China is a powerful nation and a force to be reckoned with [15] / Китай мощная нация и сила, с которой нужно считаться. 


\begin{tabular}{|c|c|}
\hline $\begin{array}{c}\text { Примеры военной метафоры в дискурсе об } \\
\text { эпидемии }\end{array}$ & Перевод фрагмента \\
\hline Novel heroes: Front-line medical couples & Новые герои: чета докторов на линии фронта \\
\hline $\begin{array}{l}\text { The battles started here, and we will definitely } \\
\text { fight to the end } \\
\text { [17] }\end{array}$ & $\begin{array}{l}\text { Бои начались здесь, и мы точно будем бороть- } \\
\text { ся до конца }\end{array}$ \\
\hline $\begin{array}{l}\text { great Chinese medical staff }<\ldots>\text { save people's } \\
\text { lives with bravery } \\
\qquad \text { [17] }\end{array}$ & $\begin{array}{l}\text { Великий китайский медицинский персонал } \\
\text { мужественно спасает жизни людей }\end{array}$ \\
\hline $\begin{array}{l}\text { securing a victory in the current fight against the } \\
\text { epidemic } \\
\text { [17] }\end{array}$ & Обеспечить победу в схватке с эпидемией \\
\hline win the war on COVID-19 & Победить в войне с коронавирусом \\
\hline defeating a deadly epidemic & Сломить смертельный вирус \\
\hline country's sacrifice for the sake of mankind & Жертвенность страны во имя человечества \\
\hline a battle China must win & $\begin{array}{l}\text { Битва, в которой Китай должен одержать } \\
\text { победу }\end{array}$ \\
\hline $\begin{array}{l}\text { Party members }\langle\ldots\rangle \text { on the frontline of the fight } \\
\text { against the virus day and night }\end{array}$ & $\begin{array}{l}\text { Члены Партии день и ночь на тинии фронта в } \\
\text { борьбе с вирусом }\end{array}$ \\
\hline
\end{tabular}

Используются и другие многочисленные метафоры, которые в рамках патриотической риторики достаточно пафосно отражают образ Великого Преодоления с целью поднятия духа нации (Таблица 4).

Так осуществляется достижение единства и сплочённости всей нации. К популярным в китайской прессе коммуникативным практикам в дискурсе об эпидемии коронавируса также относится обильное цитирование народной мудрости. Жизнь и конкретные поступки каждого человека событийны, все вместе они составляют мощную энергию единого непрерывного движения жизни по особому, не познаваемому, но естественному Пути, к которому каждый причастен. Использование исторических аллюзий и пословичных фраз о единстве и взаимной помощи во времена бедствий и опасности можно рассматривать с позиций традиционных практик реализации патриотической риторики (Таблица 5).

Итак, все названые способы (культурно-обусловленные метафоры, исторические аллюзии, народная мудрость) отражают традиционно-китайские коммуникативные практики реализации патриотической риторики.

Обилие таких коммуникативных приёмов отражает особенность китайской речемыслительной традиции. Как известно, в традиционной коммуникации китайцев отразился «окружной способ» мышления. Н. А. Спешнев отмечает, что в своих умозаключениях китайцы предпочитают принцип аналогии. Для китайца важно сначала инту-
Табл. 3. Репрезентация военной метафоры в дискурсе об эпидемии. Источник: составлено автором. 


\begin{tabular}{|c|c|}
\hline $\begin{array}{c}\text { Примеры метафоры Великого Преодоления в } \\
\text { дискурсе об эпидемии }\end{array}$ & Перевод метафоры Великого Преодоления \\
\hline $\begin{array}{l}\text { As long as we focus our thoughts and efforts } \\
\text { towards the same goal, we can forge the iron great } \\
\text { wall to contain the virus outbreak and safeguard } \\
\text { our health and homeland }\end{array}$ & $\begin{array}{l}\text { выкуем великую железную стену, чтобы сдер- } \\
\text { жать вирус }\end{array}$ \\
\hline $\begin{array}{l}\text { No mountain is unclimbable and no difficulty is } \\
\text { insurmountable as long as we work together as } \\
\text { one }\end{array}$ & $\begin{array}{l}\text { нет гор, которые нельзя покорить, и нет не- } \\
\text { преодолимых трудностей }\end{array}$ \\
\hline
\end{tabular}

Табл. 4. Репрезентация метафоры Великого Преодоления в дискурсе об эпидемии. Источник: составлено автором. итивно «почувствовать» истину, а затем, используя различные конкретные сравнения и образы (предпочтительно из истории Китая), усилить воздействие этой истины. Частотное использование пословиц и афоризмов в речи китайцев является естественным проявлением национального речевого поведения. Автор считает, что китайцам свойственен своеобразный «окружной способ» познания и коммуникации, когда тема поставлена в центр, и происходит её толкование со всех сторон [11].

Французский синолог Франсуа Жюльен в работе «Путь к цели: в обход или напрямик. Стратегия смысла в Китае и Греции» также пишет, что Запад предпочитает «привычный и нормальный подход к миру напрямую», в то время как Китай - «окружной, сторонний путь» $[4$, с. 7$]$.

Однако исследование англоязычных китайских СМИ показало, что китайская модель «отсутствия всякого принуждения» и «окружного, стороннего пути» достижения цели в случаях конфликта, угрозы или вызова со стороны внешних сил, когда коммуникация выходит за пределы «мы-группы», совмещается с отзеркаливанием приёма оппонента [8, с. 40-42] - отзеркаливанием прямой и жёсткой ультимативной риторики: "China-US relations stand at a crucial point. It is a risky choice for the US to choose a path of military engagement, in which it won't be able to win» [19] / Отношения между Китаем и США находятся в критической точке. Это рискованный выбор для США выбрать путь военного столкновения, в котором они не смогут победить.

Тем не менее дискурсивный и интент-анализ анализ текстов китайских СМИ на английском языке показывает, что нарочито-агрессивная позиция Китая по ряду критических вопросов является, по сути, - с позиций патриотической риторики - оборонительной. В свете жёстких нападок со стороны США и откровенной демонизации Китая в американской прессе и американской политике, особенно в критические моменты, Китай вынужден защищаться.

При этом используются и конкретные ресурсы самого английского языка. Так, искусно применяется англоязычная игра слов (Trump trump: фамилия президента США Трампа - козырная карта): The China card is a trump card that US President Donald Trump won't discard [19] / Китайская карта - это козырная карта, которую президент США Дональд Трамп не отбросит. 


\begin{tabular}{|c|c|}
\hline $\begin{array}{c}\text { Примеры китайских пословиц о единстве } \\
\text { и взаимной помощи во времена бедствий в } \\
\text { дискурсе об эпидемии }\end{array}$ & Перевод фрагмента \\
\hline $\begin{array}{l}\text { These efforts unleash huge energy like small } \\
\text { streams converging into the ocean }\end{array}$ & $\begin{array}{l}\text { Эти усилия высвобождают огромную энер- } \\
\text { гию, как маленькие потоки, сходящиеся в } \\
\text { океан. }\end{array}$ \\
\hline $\begin{array}{l}\text { As a Chinese proverb goes, all sides come to help } \\
\text { when one is struck by disaster }\end{array}$ & $\begin{array}{l}\text { Как гласит китайская пословица, все прихо- } \\
\text { дят на помощь, когда у кого-то бедствие. }\end{array}$ \\
\hline $\begin{array}{l}\text { A Chinese proverb says that in time of safety, } \\
\text { do not forget danger and always be prepared for } \\
\text { emergencies with preventive measures to ensure } \\
\text { safety }\end{array}$ & $\begin{array}{l}\text { Как гласит китайская пословица, не забывай- } \\
\text { те об опасности даже в момент безопасности } \\
\text { и всегда будьте готовы к чрезвычайным ситу- } \\
\text { ациям с превентивными мерами по обеспече- } \\
\text { нию безопасности. }\end{array}$ \\
\hline
\end{tabular}

Создаётся забавный англоязычный каламбур: a trump card - Trump won't discard, который апеллирует и к мыслям, и к эмоциям читательской аудитории.

В отношении критических событий сочетание традиционно-китайских коммуникативных практик и практик, свойственных англоязычной масс-медийной коммуникации, выливается в угрожающую риторику, в насмешливую игру слов, в беспощадный сарказм: «It's understandable that people's nerves are on edge at a time like this. That's why the Wall Street Journal's "China is the Real Sick Man of Asia" provoked a strong reaction among ordinary citizens and officials alike. $\langle\ldots\rangle$ Let's hope The New York Times does a better job of covering the US chapter of the coronavirus tragedy than it's done so far in China» [16] / Понятно, что в такое время нервы у людей на пределе. Вот почему заявление Wall Street Journal Китай - настоящий больной в Азии вызвало бурную реакцию как у простых граждан, так и у чиновников. Будем надеяться, что New York Times напишет главу американской трагедии о коронавирусе лучше, чем главу о Китае.

Следует повторить, однако, что с позиций патриотической риторики угрожающий сарказм, насмешливая игра слов являются защитной реакцией Китая на нападки США.

Патриотическая риторика во многом связывается с ролью Коммунистической Партии Китая. В прессе освещаются руководящие действия КПК в борьбе с коронавирусом: «Since the outbreak, the Central Committee of the Communist Party of China (CPC) has exercised leadership and coordinated work in all aspects, while the Party committees and governments at all levels have resolutely implemented instructions. $<\ldots>$ Xi's important speeches and instructions have charted the course for comprehensively enhancing the epidemic prevention and control work» [13] / С момента вспышки эпидемии Центральный Комитет Коммунистической партии Китая (КПК) осуществлял руководство и координировал работу во всех аспектах, а партийные комитеты и правительства на всех уровнях решительно выполняли инструкции. $<. .>$ Важные выступления и поручения Си наметили курс на всестороннее усиление работы по профилактике и борьбе с эпидемией.
Табл. 5. Пословицы о единстве и взаимной помощи во времена бедствий в дискурсе об эпидемии. Источник: составлено автором 
Разъясняется преимущество социалистической системы Китая, позволившей мобилизовать ресурсы: «The institutional strength of China's socialist system which can bring together the resources necessary to take on great tasks is the key to win the battle against the epidemic» [13] / Институциональная мощь китайской социалистической системы, которая может объединить ресурсы, необходимые для выполнения великих задач, является ключом к победе в борьбе с эпидемией.

Действия КПК и правительства расцениваются как правильные и лучшие в сопоставлении с мировым уровнем, Китай наделяется ролью спасителя человечества: country's sacrifice for the sake of mankind [18] / жертвенность страны ради спасения человечества.

Для подтверждения привлекаются цитаты мировых лидеров и главы Всемирной организации здравоохранения: «Just as what World Health Organization Director-General Tedros Adhanom Ghebreyesus said, the high speed and massive scale of China's moves are rarely seen in the world» [13] / Как сказал генеральный директор Всемирной организации здравоохранения Тедрос Адханом Гебрейесус, высокая скорость и масштаб мер, предпринятых Китаем, редко наблюдаются в мире.

Заголовки статей убеждают в высоком призвании Китая спасти мировую экономику: China must save globalization from epidemic [14] / Китай должен спасти глобализацию от эпидемии.

Таким образом, проведённое исследование позволило сделать следующие выводы. В целом в китайских СМИ на английском языке патриотическая риторика носит как идеологический характер, так и нравственный, широко демонстрируя заботу государства и Коммунистической Партии Китая о безопасности, процветании и развитии страны, с одной стороны, и сохраняя моральные ценности совместного труда и готовности пожертвовать личными интересами во благо общества, с другой.

Патриотическая риторика может рассматриваться как эффективное средство социального конструирования и социального управления, более того, она, вероятно, и является наиболее естественным таким средством, затрагивающим ключевую человеческую ценность любви к родине.

В англоязычных китайских СМИ патриотическая риторика реализуется как через актуализацию положительных ценностей: консолидация нации, гордость за достижения страны, руководящая роль Коммунистической Партии Китая, так и анти-ценностей: борьба с коррупционными проявлениями в стране, отстаивание позиции Китая по вопросам территориальной целостности и спорных территорий, противостояние с США по экономическим и военным вопросам. Патриотическая повестка может тематически варьировать в зависимости от текущей ситуации и включаться в риторику о новых социальных или внешних угрозах и вызовах.

Высокая степень централизации государственной власти в Китае и тот факт, что китайские СМИ учреждены партийно-государственными органами, обусловливают общую запрограммированную линию речевого поведения Китая на реализацию риторики патриотизма. Происходит это как посредством традиционно-китайских коммуникативных практик, так и с применением практик, свойственных англоязычной коммуникативной традиции. 


\section{Литература}

1. Александер Дж. Смыслы социальной жизни: культурсоциология. - М.: Праксис. 2013. 640 с.

2. Верещагина А. В., Ковалев В. В., Самыгин С. И. Социокультурные ресурсы семьи по формированию патриотизма // Гуманитарные, социально-экономические и общественные науки. 2017. № 3. С. 33-37.

3. Гуляихин В. Н. Политика и патриотизм в современной России // Социодинамика. 2013. № 9. С. 1-19.

4. Жюльен Ф. Путь к цели: в обход или напрямик. Стратегия смысла в Китае и Греции. - М.: Моск. филос. фонд, 2001. 359 с.

5. Зенгер Х. фон. Стратагемы : О китайском искусстве жить и выживать: Впервые полное соврем. прочтение всех 36 знаменитых стратагем, истин. воплощения трехтысячелетней мудрости. Т. 1: Стратагемы 1-18 / общ. ред., вступ. ст. и коммент. В. С. Мясникова. - М.: ЭКСМО, 2004. 510 с.

6. Зенгер Х. фон. Стратагемы : О китайском искусстве жить и выживать: Впервые полное соврем. прочтение всех 36 знаменитых стратагем, истин. воплощения трехтысячелетней мудрости. Т. 2: Стратагемы 19-36 / общ. ред., вступ. ст. и коммент. В. С. Мясникова. - М.: ЭКСМО, 2004. 1022 c.

7. Лубский А. В. Гражданский патриотизм: о совместимости патриотизма и гражданственности в российском обществе // Гуманитарий Юга России. 2017. T. 23. № 1. С. 42-59.

8. Николаева О. В. Стратагемность речевой культуры в китайских СМИ на английском языке. - Владивосток: Изд-во Дальневост. ун-та, 2019. 104 с.

9. Павлов А. В. Патриотизм: социально-философский подход // Философия и современность. 2018. № 2. С. 83-94.

10. Санина А. Г. Патриотизм и патриотическое воспитание в современной России // Социологические исследования. 2016. № 5. C. 44-53.

11. Спешнев Н. А. Китайцы. Особенности национальной психологии. - СПб.: KАРО, 2017. 336 c.
12. Chen Weihua. US intimidation won't succeed in bringing nations to their knees [Электронный документ] // China Daily (сайт), 2018, Oct. 08. URL: http:// www.chinadaily.com.cn/a/201808/10/ WS5b6cd39da310add14f384fa3.html (дата обращения: 27.10.2018).

13. China confident to win decisive victory in fight against epidemic [Электронный документ] //China Daily (сайт), 2020, Feb. 09. URL: https://www.chinadaily.com.cn/a/202002/09/ WS5e3fc2daa3101282172760d1.html (дата обращения: 26.02.2020).

14. China must save globalization from epidemic [Электронный документ] // Global Times (сайт), 2020, March 9. URL: https://www.globaltimes.cn/content/1182076. shtml 1. (дата обращения: 09.03.2020).

15. China readies as Trump's trade war plan spells failure [Электронный документ] // People’s Daily (сайт), 2018, March 23. URL: http://en.people.cn/n3/2018/0323/c900009440910.html (дата обращения: 20.10.2018).

16. Headlines in New York Times are misleading [Электронный документ] // China Daily (сайт), 2020, Feb. 28. URL: https://www.chinadaily.com.cn/a/202002/28/ WS5e58cab9a31012821727b1f8.html (дата обращения: 28.02.2020).

17. Novel heroes: Front-line medical couples save lives with love [Электронный документ] // China Daily (сайт), 2020, Feb. 27. URL: https:// www.chinadaily.com.cn/a/202002/27/ WS5e56f168a31012821727a976.html (дата обращения: 27.02.2020).

18. Solidarity, dedication will help win the war on COVID-19 [Электронный документ] //ChinaDaily(сайт),2020,Feb.26.URL:https:// epaper.chinadaily.com.cn/a/202002/26/ WS5e55ba3aa310a2fabb7a26f9.html (дата обращения: 26.02.2020).

19. Washington must curb warmongering among right wing. [Электронный документ] // Global Times (сайт), 2020, Feb. 27. URL: https://www.globaltimes.cn/content/1181034. shtml (дата обращения: 28.02.2020). 


\section{Olga V. NIKOLAEVA}

Ph. D. (in Philology), Full Professor of Linguistics and Intercultural Communications Department, Oriental Institute School of Regional and International Studies, Far Eastern Federal University (Vladivostok, Russia).

E-mail:nikolaeva.ov@dvfu.ru

\section{Communication Techniques in Implementation of the Patriotic Rhetoric through Chinese Media in English}

UDC $81-23$

patriotism,

patriotic rhetoric,

Chinese media in English,

pragmatics,

communication

techniques,

verbal behavior patterns, frames of mind and speech doi: dx.doi.org/10.24866/2542-1611/2020-1/23-33

The paper is devoted to the issues of pragmatic effectiveness of China's patriotic rhetoric in the Chinese media in English. Chinese traditional and modern mass-media communication techniques are identified. The author defines the role of figurative actualization of the external threat concept through the metaphor of war in relation to critical economic and social factors, and the image of the great overcoming used to raise the patriotic spirit of the nation. Historical allusions and folk wisdom are presented as tools of traditional patriotic rhetoric in China. Modern mass-media communication practices of China include specific resources of the English language and the English-language speech tradition. In the coverage of critical events China employs harsh warning rhetoric, pun, and sarcasm. In light of the harsh attacks from the United States and the demonization of China in the American press and American politics, the communication practices of China's patriotic rhetoric, despite their deliberate external aggressiveness, are viewed as the reaction of a defensive nature.

For citation: Nikolaeva O. V. Communication Techniques in Implementation of the Patriotic Rhetoric through Chinese Media in English // Oriental Institute Journal. 2020. № 1. P. 23-33. doi: dx.doi.org/10.24866/2542$1611 / 2020-1 / 23-33$

\section{References}

1. Aleksander Dzh. Smysly sotsial'noj zhizni: kul'tursotsiologiya. - M.: Praksis. 2013. $640 \mathrm{~s}$.

2. Vereshhagina A. V., Kovalev V. V., Samygin S. I. Sotsiokul'turnye resursy sem'i po formirovaniyu patriotizma // Gumanitarnye, sotsial'no-ehkonomicheskie i obshhestvennye nauki. 2017. № 3. S. 33-37.

3. Gulyaikhin V. N. Politika i patriotizm v sovremennoj Rossii // Sotsiodinamika. 2013. № 9. S. 1-19.

4. ZHyul'en F. Put' $\mathrm{k}$ tseli: $\mathrm{v}$ obkhod ili napryamik. Strategiya smysla v Kitae i Gretsii. - M.: Mosk. filos. fond, 2001. 359 s.

5. Zenger KH. fon. Stratagemy : $\mathrm{O}$ kitajskom iskusstve zhit' i vyzhivat': Vpervye polnoe sovrem. prochtenie vsekh 36 znamenitykh stratagem, istin. voploshheniya trekhtysyacheletnej mudrosti. T. 1: Stratagemy 1-18 / obshh. red., vstup. st. i komment. V. S. Myasnikova. - M.: EHKSMO, 2004. 510 s.

6. Zenger KH. fon. Stratagemy : O kitajskom iskusstve zhit' i vyzhivat': Vpervye polnoe sovrem. prochtenie vsekh 36 znamenitykh stratagem, istin. voploshheniya trekhtysyacheletnej mudrosti. T. 2: Stratagemy 19-36 / obshh. red., vstup. st. i komment. V. S. Myasnikova. - M.: EHKSMO, 2004. 1022 s.
7. Lubskij A. V. Grazhdanskij patriotizm: o sovmestimosti patriotizma i grazhdanstvennosti v rossijskom obshhestve // Gumanitarij YUga Rossii. 2017. T. 23. № 1. S. 42-59.
8. Nikolaeva
O. V. Stratagemnost' 
rechevoj kul'tury $\mathrm{v}$ kitajskikh SMI na anglijskom yazyke. - Vladivostok: Izd-vo Dal'nevost. un-ta, 2019. $104 \mathrm{~s}$.

9. Pavlov A. V. Patriotizm: sotsial'nofilosofskij podkhod // Filosofiya i sovremennost'. 2018. № 2. S. 83-94.

10. Sanina A. G. Patriotizm i patrioticheskoe vospitanie $\mathrm{v}$ sovremennoj Rossii // Sotsiologicheskie issledovaniya. 2016. № 5. S. 44-53.

11. Speshnev N. A. Kitajtsy. Osobennosti natsional'noj psikhologii. - SPb.: KARO, 2017. $336 \mathrm{~s}$.

12. Chen Weihua. US intimidation won't succeed in bringing nations to their knees [EHlektronnyj dokument] // China Daily (sajt), 2018, Oct. 08. URL: http:// www.chinadaily.com.cn/a/201808/10/ WS5b6cd39da310add14f384fa3.html (data obrashheniya: 27.10.2018).

13. China confident to win decisive victory in fight against epidemic [EHlektronnyj dokument] // China Daily (sajt), 2020, Feb. 09. URL: https:// www.chinadaily.com.cn/a/202002/09/ WS5e3fc2daa3101282172760d1.html (data obrashheniya: 26.02.2020).

14. China must save globalization from epidemic [EHlektronnyj dokument] // Global Times (sajt), 2020, March 9. URL: https:// www.globaltimes.cn/content/1182076. shtml 1. (data obrashheniya: 09.03.2020).
15. China readies as Trump's trade war plan spells failure [EHlektronnyj dokument] // People's Daily (sajt), 2018, March 23. URL: http://en.people.cn/n3/2018/0323/ c90000-9440910.html (data obrashheniya: 20.10.2018).

16. Headlines in New York Times are misleading [EHlektronnyj dokument] // China Daily (sajt), 2020, Feb. 28. URL: https://www.chinadaily.com.cn/a/202002/28/ WS5e58cab9a31012821727b1f8.html (data obrashheniya: 28.02.2020).

17. Novelheroes:Front-linemedicalcouples save lives with love [EHlektronnyj dokument] // China Daily (sajt), 2020, Feb. 27. URL: https://www.chinadaily.com.cn/a/202002/27/ WS5e56f168a31012821727a976.html (data obrashheniya: 27.02.2020).

18. Solidarity, dedication will help win the war on COVID-19 [EHlektronnyj dokument] //China Daily (sajt), 2020, Feb.26.URL:https:// epaper.chinadaily.com.cn/a/202002/26/ WS5e55ba3aa310a2fabb7a26f9.html (data obrashheniya: 26.02.2020).

19. Washington must curb warmongering among right wing. [EHlektronnyj dokument] // Global Times (sajt), 2020, Feb. 27. URL: https://www.globaltimes.cn/content/1181034. shtml (data obrashheniya: 28.02.2020). 